\title{
Saudi Female EFL Instructors' Perceptions of the Effects of Professional Development on Their Self-Efficacy
}

\author{
Khawlah H. Almuhammadi ${ }^{1}$, Hussein M. Assalahi ${ }^{1}$ \& Abeer Ahmed Madini ${ }^{1}$ \\ ${ }^{1}$ English Language Institute, King Abdulaziz University, Jeddah, Saudi Arabia \\ Correspondence: Khawlah H. Almuhammadi, English Language Institute, King Abdulaziz University, Jeddah, \\ Saudi Arabia.
}

Received: July 7, 2020

Accepted: September 1, 2020

Online Published: September 21, 2020

doi: 10.5539/elt.v13n10p74

URL: https://doi.org/10.5539/elt.v13n10p74

\begin{abstract}
This research explores female EFL instructors' perceptions of the effect of the professional development provided by the English Language Institute (ELI) at King Abdul-Aziz University (KAU) on their self-efficacy and the type of professional development training that they feel has the greatest effect on their sense of self-efficacy. This research is based on Bandura's (1977) social cognitive theory and its subset of self-efficacy. In order to achieve its objective, this qualitative study incorporated semi-structured interviews with six EFL female instructors within the ELI at KAU, Saudi Arabia. The study results revealed that the instructors had positive perceptions of the professional development they received at the ELI in terms of enhancing their efficacy beliefs, as it enabled an opportunity for professional enhancement, positively influenced teaching practice to help students' learning, and developed a positive atmosphere of collegiality and collaboration. Additionally, the participants demonstrated a positive attitude toward the ELI's mentoring program, as it enabled them to be inspired by an expert in the field, improved their teaching competencies, and created a feeling of professionalism. However, the participants held a conflicting view of the effect of classroom observation on instructors' self-efficacy. Some believed that observations represent an important professional development tool that helps improve their performance, while others perceived it as a source of efficacy doubt. Based on the research results, this study bridged a gap in the current literature and contributed to knowledge on EFL instructors' self-efficacy and how it could be influenced by professional development activities.
\end{abstract}

Keywords: EFL, professional development, self-efficacy, Mentoring program, classroom observation, socio-cognitive theory

\section{Introduction}

A wealth of academic research has been conducted on the instructional effectiveness of teachers (Chingos \& Peterson, 2011; Klassen \& Tze, 2014; Palardy \& Rumberger, 2008; Rice, 2003), and a large number of researchers have attempted to explore how student performance could be affected by teaching behavior and practices (Blömeke, Olsen, \& Suhl, 2016; Chetty, Friedman, \& Rockoff, 2013; Goe, 2007). However, little attention has been paid to factors that might influence teaching behavior and practices. An understanding of antecedent factors that might improve teaching could offer a wealth of information to help increase both student achievement and the effectiveness of teachers. For example, teacher efficacy could have an impact on the learning and teaching process and is defined as the extent of a teacher's belief in their ability to affect student performance (Wheatley, 2005).

A range of studies have identified a positive relationship between classroom instructional quality (Justice, Mashburn, Hamre, \& Pianta, 2008) and students' academic achievement (Kurt, Güngör, \& Ekici, 2014; Shidler, 2009) and teacher self-efficacy. Bandura (1993) posited that the relationship between achievement and efficacy could be explained by the learning environment that teachers cultivate for their students. Teacher efficacy, for example, can be a determining factor in the effort teachers expend, how they respond to challenging situations, the goals they set for both themselves and their students, and their level of motivation in creating a positive learning environment. Positive and negative instructional practices can be created by certain factors, which can, in turn, have an impact on student achievement.

Given instructors' self-efficacy that's significant, as it has a positive effect on the teaching and learning process and on increasing student motivation and achievement. Consequently, it is important that related constructs, such 
as professional development, be studied in relation to instructors' self-efficacy perception. investigates how professional development programs for instructors could implement support strategies aimed at effectively increasing teachers' self-efficacy. Therefore, this study has two goals: (1) to examine how EFL instructors within the English Language Institute (ELI) at King Abdul-Aziz University (KAU) perceive the effect of professional development on their self-efficacy and (2) to investigate the perspectives of EFL instructors regarding factors that affect their sense of self-efficacy. This research limited itself to the female section of the ELI at KAU, as the male and female sections have different administrators, and professional development are completely separate, it is likely that the instructors in the two sections could experience and perceive professional development very differently.

\subsection{Socio-Cognitive Theory of Self-Efficacy}

Bandura (1986) proposed social cognitive theory, according to which individuals self-regulate cognitive processes and behaviors instead of reacting directly to events. This perspective arises from the belief that "individuals are capable of exercising a degree of control over their thoughts, feelings, motivation, and actions" (Pajares, 2003, p. 7) following a self-interpretation of their performance.

This control has the capacity to affect subsequent actions and behaviors. Bandura (1986) posited that behavior could be predicted more effectively by the belief that individuals have in their abilities, as opposed to their actual capacities. This means that an individual's self-belief is the principal motivator in their academic accomplishments. This belief determines "how well knowledge and skill are acquired" (Pajares, 2003, p. 8).

\subsection{Where Does Efficacy Come From}

Bandura (1977) outlined four contributors to self-efficacy:

(a) Successful performance (also known as mastery experiences) is most likely to boost self-efficacy, as the individual is directly involved in successfully completing tasks.

(b) Vicarious experience (modeling) is such that, if the individual observes another person being successful or unsuccessful in a task, this individual comes to believe that they are also capable of succeeding.

(c) Verbal persuasion is influential when other people tell the subject that they believe that the subject has the ability to succeed, as the subject overcomes self-doubt. Self-efficacy arising from verbal persuasion is not long-lasting, for the reason that as soon as difficulties arise, or the possibility of failure is revealed, the subject's self-efficacy declines.

(d) Emotional status is centered on the subject's anxiety, guiding the subject away from a path of avoidance. This technique is frequently used in assisting individuals in overcoming phobias. If the subject shakes or sweats before approaching a task, the subject may see this as their inability to perform the task. Generally, there will be improvements in self-efficacy with repeated experiences of success, and it will decline in proportion to the amount of failure experienced.

\subsection{Instructors' Professional Development}

Professional development can be defined as a range of activities intended to equip individuals with the tools, training experiences, and knowledge needed to expand their capacities in their field of practice (Mizell, 2010). In the educational context, professional development is an essential construct that contributes to a number of positive changes, such as improving educational institutions by increasing teachers' instructional abilities, improving student learning (Girvan, Conneely, \& Tangney, 2016; Ross \& Bruce, 2007), and boosting teachers' self-efficacy (Karimi, 2011; Klassen \& Chiu, 2010; Zambo \& Zambo, 2008).

Quality professional development activities are frequently seen as crucial to the growth of faculty members, as they contribute to achieving the mission of the educational institutions. Another perceived target of professional development is helping instructors develop pedagogical competence. The expectation is that, by taking part in professional development, instructors will optimize classroom performance, which will enhance learners' educational outcomes. According to Mizell (2010), well-designed professional development activities yield a range of advantages for all members of the educational institution. Taking part in professional development training equips educators with suitable knowledge to facilitate student achievement and enables them to become more aware of hindrances to students' educational paths. This knowledge enhances the classroom experience for both teachers and students, thereby improving student outcomes.

Mizell (2010) claimed that newly graduated instructors do not have sufficient knowledge to perform the role of a successful instructor, as colleges and universities are unable to offer a wide variety of enriching practical training deemed essential for graduates. Consequently, newly graduated instructors who do not participate in further 
professional development opportunities do not upgrade their expertise and will not be able to be effective as a teacher.

Several studies have asserted that the most effective professional development programs provide participants with relevant content to strengthen their curricula knowledge and enhance their pedagogical performance, thereby beneficially influencing their students' educational outcomes (Harris, Cale, \& Musson, 2011; Buczynski \& Hansen, 2010; Tantawy, 2020). Aminudin (2012) indicated that professional development in an educational setting should provide instructors with the essential knowledge base and expertise to help them make necessary adjustments.

According to Garet, Porter, Desimone, Birman, and Yoon (2001), the key characteristics of effective professional development experiences include providing a rich set of content-related educational knowledge, presenting opportunities for active and practical training, and delivering a collaborative form of professional development experience that allows knowledge exchange, performance improvement, and interaction between individuals who share the same goals and values.

In summary, this review has shown that professional development appears to have a strong influence on the educational spectrum. As instructors acquire new knowledge, learn how to apply and use this knowledge, and then converting it into practice to enhance their students' achievements.

\subsection{Instructors' Professional Development and Self-Efficacy}

Coldwell (2017) demonstrated that a number of existing studies have linked instructors' professional development experiences with a higher level of self-efficacy. He further indicated that effective, well-designed professional development opportunities result in instructors expanding their knowledge, enabling them to become more assured about their teaching abilities and empowered as successful teachers. Additionally, such factors as growing knowledge, a feeling of self-assurance, and willpower were deemed to be strongly correlated to high efficacy beliefs among instructors.

Although self-efficacy appears to have a strong effect on the general practice of instructors and their ability, it does not evolve independently, as several researchers have indicated that there is a relationship between instructors' acquired knowledge, performance and level of self-efficacy (Fives \& Buehl, 2012; Hoy, Davis, \& Pape, 2006; Pajares, 1992).

Nevertheless, when instructors do not have sufficient levels of knowledge and skills, they may encounter a considerable degree of stress regarding their performance, which may lead them to question their teaching ability and feel less effective (Ashcraft \& Moore, 2009). In essence, although self-efficacy is a significant factor affecting the teaching process, it cannot independently lead to efficient actions if the instructor does not possess essential teaching skills (Schunk, 1991).

Consequently, an effective way of improving instructors' knowledge and teaching practice and offering empowering opportunities that enhance their efficacy beliefs is to create well-designed professional development activities that help educators feel more efficacious (Darling-Hammond \& McLaughlin, 2011).

\subsection{State of the Professional Development Program at the ELI}

The ELI promotes continuous professional development among faculty members, with the aim of creating and providing a quality learning and teaching experience for both students and faculty members. In this regard, this part of the paper will review a number of studies conducted at the ELI to shed light on the role and effect of professional development training provided by the ELI.

A recent study by Roy, Rahim, and Khojah (2018) investigated the in-campus professional development experiences of EFL instructors at the ELI. The aim of this study was to examine instructors' impressions of the attribute of the Cambridge University Press' course, Train the Trainer. The study found that the course had a beneficial outcome on the participants, as it equipped them with up-to-date skills and knowledge in the EFL context and provided a positive professional development experience for faculty members.

In terms of classroom observation, studies were conducted by Shukri (2014) and Shousha (2015) to gain a deeper understanding of EFL instructors' experiences with classroom observation and determine how it contribute to instructors' professional growth. The studies reported comparable results, concluding that the instructors affirmed the beneficial function of classroom observation as a vehicle for professional development activities, as it promoted the teaching and learning process by providing valuable feedback to them. Additionally, it could significantly enhance the overall instructing experience, which could ultimately contribute to instructors' confidence. 
Shukri and Leil (2017) examined instructors' perceptions of the formal mentoring program at the ELI. The study highlighted the significance of the mentoring program as an appropriate means of professional development and provided recommendations to improve the mentoring program. A similar study conducted by Asif and Khojah (2020) reported a similar positive outcome in relation to the ELI's mentoring program.

This overview of the literature on the ELI context has emphasized the importance of professional development activities. Although numerous studies have investigated the professional development program from different angles, none have explored the relationship between such professional development training and its effect on EFL instructors' self-efficacy. This provided the impetus for the current research in terms of exploring how instructors perceive their experience of the professional development training provided by the ELI at KAU with regard to their efficacy beliefs and, more specifically, what type of professional development training is most effective in relation to instructors' sense of self-efficacy.

In order to achieve the aim of the study, the following research questions were formulated:

1. How do EFL instructors within the ELI at KAU perceive the effect of professional development on their self-efficacy?

2. What are EFL instructors' perspectives regarding the factors affecting their sense of self-efficacy?

\section{Method}

\subsection{Participants}

The study participants comprised six randomly selected Saudi female English language instructors within the ELI at KAU, all of whom were foundation year instructors with experience ranging from one to six years of teaching at the ELI. They were all taking part in various types of professional development activities within the same setting.

\subsection{Instruments}

This study adopted a qualitative approach to investigate instructors' perceptions of the effect of professional development on their sense of self-efficacy. In order to obtain a detailed understanding of the research topic from the instructors' points of view, a semi-structured interview was utilized as the main instrument to collect data from the participants.

\subsection{Procedures}

The semi-structured interview questions were designed in light of the two main research questions to serve the main objective of the research. Subsequently, piloting for the semi-structured interview questions was performed with two English instructors at the ELI in order to determine the interviewees' understanding of the questions. After the piloting process, data collection approval was obtained from the Unit of Graduate Studies and Academic Research at the ELI. Upon approval, the data collection procedure commenced by first contacting the potential participants by e-mail. Due to the unfortunate Coronavirus pandemic, the interviews were carried out with the participants by e-mail or phone.

\subsection{Data Analysis}

The data analysis stage began immediately upon completion of the data collection process. Through the use of NVivo, the semi-structured interview data were analyzed in order to extract potential codes and themes.

\section{Results}

Three main themes emerged from the participants' responses, the first of which concerned professional development activities contributing to instructors' self-efficacy. The second involved mentoring programs customized to instructor preparation. The third theme covered instructors' conflicting views regarding classroom observation. 


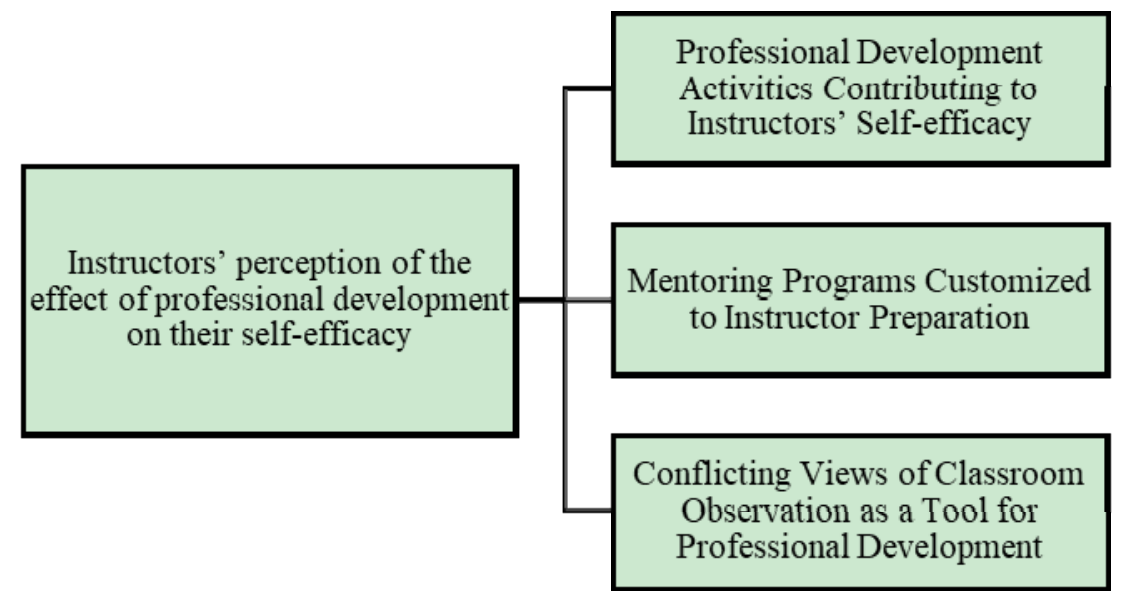

Figure 1. Instructors' Perceptions of the Effects of Professional Development on Their Self-Efficacy

\subsection{Professional Development Activities Contributing to Instructors'Self-Efficacy}

The analysis of the responses revealed that most of the participants believed that the professional development activities had allowed them to grow professionally and had provided them with a strong conceptual and theoretical framework that had improved their self-efficacy. A number of comments from the participants regarding this are presented below:

"I wasn't expecting professional development activities to be so beneficial, they have provided me with some valuable tools and information that I will be able to use in my classroom" (Participant A)

"it encourages me to keep on developing ... and that gives me a sense of satisfaction" (Participant C)

Moreover, Participant $\mathrm{F}$ stated that she felt more confident in her abilities to improve her teaching practices, which she felt would influence student achievement.

"I feel that I became so much more confident because I learned new ways of engaging with students and I have incorporated all these into my teaching"

Participant $\mathrm{E}$ added that undertaking professional development alongside colleagues led to increased positivity, productivity, and better collaboration:

"the collaborative nature of the mentoring gave me a since that I'm not alone, you feel more part of the team, planning together and sharing ideas to further apply it in the classroom".

\subsection{Mentoring Programs Customized to Instructor Preparation}

The participants indicated that the formal mentoring program at the ELI has had a positive influence on them.

Participant A mentioned that the activities in which she participated with her mentors and what she learned enabled her to improve her teaching approach.

"the meeting with my mentor enrich my knowledge by talk about thing related to teaching such as lesson plan, classroom management...I do benefit from her comments on my lesson plan, she also provides me with another resources concerning lesson plans...we do even discuss varieties of topic including ways to teach every and each language skill".

Participant $\mathrm{C}$ stated that her belief in her own capabilities had been enhanced with the support of her mentor:

"The guidance and support I received from my mentor and my overall mentoring experience made me more motivated, confident, and more involved in the work knowing that I am doing good"

Participant D commented,

"It was a unique experience, I have learned a lot of strategies ... with this guidance and help I felt like I have control over what I am doing and aware of what I am capable to do, so I think am doing things good"

The participants suggested that the mentoring program provided them with practical strategies that helped them become successful instructors and allowed them to become more professional, improve their teaching, and develop self-efficacy. 


\subsection{Conflicting Views of Classroom Observation as a Tool for Professional Development}

$\mathrm{R}$ Some of the points raised by the instructors in relation to their efficacy beliefs can be traced to their experiences of classroom observation and the corresponding feedback. Participant $\mathrm{C}$ described how one classroom observation had helped increase her confidence in her teaching abilities and motivated her to improve:

"When my classroom observation went well, and I received positive comments, I felt quite proud to be a teacher and I was more motivated to do better".

Participant D stated that classroom observations could be beneficial, as they provided her with the opportunity to reflect on her practice:

"Observations are sometimes beneficial to me. I get a new viewpoint on my teaching, so it prompts me to engage in detailed reflection on my practice in the classroom to see if I need to change some of my teaching strategies or try to implement new ones".

However, some participants provided different views of the feedback on classroom observations and how it made them doubt their efficacy. Participant E mentioned how an observer's evaluation had a negative impact on her confidence as an instructor:

"It made me question my confidence as a teacher, you thought you were doing well, but then the observer evaluated what you were doing as ineffective ... it's disappointing"

However, unfavorable feedback from the observer functioned as a motivational trigger for improvement. She subsequently addressed this by saying,

"There is always room for improvement, the first experience with observation was not a good one. The feedback I received made me less confident. So, I decided to learn more about it by reading related articles and watching YouTube videos"

Another concern raised by Participant A was that the observation might present a partial view of the instructor's real performance, as such, the observation might not always be a fair tool for measuring instructors' true ability:

"It is an experience that makes you stressed. You keep thinking, 'What if something goes wrong?' It is unfair that your work as a teacher is being evaluated based on one hour with one class...it is only a glance at my overall ability as a teacher".

\section{Discussion}

This part of the paper addresses the results of the study with reference to the two main research questions and provides interpretations of the findings. It also clarifies the results in relation to the existing literature.

With regard to the first research question-How do EFL instructors within the ELI at KAU perceive the effect of professional development on their self-efficacy? - the instructors were generally in agreement that the professional development activities at the ELI assisted them in becoming better professionals and boosted their confidence in their teaching abilities. This finding accords with that of other studies on the manner in which professional development activities enhance teacher confidence with regard to performance (Buczynski \& Hansen, 2010; Harris et al., 2011; Tantawy, 2020).

It has been stated that instructor self-efficacy can be boosted with the knowledge, experience, and abilities the instructor acquires through professional training. According to Bandura (1997), self-efficacy can only be positively enhanced with "compelling feedback that forcefully disrupts the pre-existing disbelief in one's capabilities" (p. 82). Therefore, professional development activities boost instructors' beliefs about their capacity when it is effective, as they foster positive changes to instructors' prior beliefs about their own ability.

Additionally, the respondents reported that working in a collaborative and collegiate atmosphere made them feel more motivated, enabled them to become more productive, and boost their self-efficacy by improving their emotional state. When teachers believe that both their colleagues and institution support them and share their values, there is a greater likelihood they will have the confidence to try new teaching strategies, the success of which could further boost their efficacy. Similar results have been reported by Shousha (2015) in the ELI context.

The findings of this research can further relate to Bandura's (1997) sources for self-efficacy, in particular, mastery experience. Teaching will always be a highly demanding profession that imposes numerous requirements on teachers, who need to undergo effective preparation to fulfill demands. Professional development activities offer instructors mastery experiences related to the ways in which they can manage their students in the classroom as well as their instruction and pedagogical-content knowledge. Another source of 
instructor self-efficacy in this study is the emotional state, that is, a collaborative and collegiate atmosphere will improve an instructor's emotional state.

Due to the quality of teaching outcomes and student attainment potentially being affected by the extent to which instructors believe in their own abilities, those who frame educational policy should consider providing high-quality professional development programs with the specific intention of improving teaching techniques and subject knowledge, which will lead to instructors feeling more efficacious. This is in accordance with past research on the strong correlation between teachers' professional development training and sense of self-efficacy (Karimi, 2010; Klassen \& Chiu, 2010; Zambo \& Zambo, 2008).

With regard to the second research question - What are EFL instructors' perspectives regarding the factors affecting their sense of self-efficacy? - the participants demonstrated a positive attitude in relation to mentoring as an element of the professional development training at ELI. It enabled them to be inspired by an expert in the field, and helped improve their teaching competencies. However, despite the majority of the interviewed instructors stating that the professional development activities did have an overall positive outcome, some had a conflicting view of classroom observation as a tool for professional development. Some viewed classroom observation as a boost to their sense of self-efficacy, while others perceived it as engendering efficacy doubt due to the feedback they received.

In referring to Bandura's (1997) sources of self-efficacy, mentoring programs and classroom observation can be seen as activities that bring together all sources of self-efficacy. These sources are verbal persuasion in the form of feedback from a mentor and observers; vicarious experiences in the form of classroom observations and the observation of mentors and colleagues; mastery experiences in the form of providing instructors with different opportunities to experience success and improvement in their performance; and emotional status, which appears to boost teachers' emotional status by making them feel more secure and supported, due to an encouraging working atmosphere and mentor availability.

Bandura (1997) suggested that vicarious experience is a significant way in which confidence can be raised, a point substantiated in this study. Bandura claimed that people will deliberately search for successful role models in striving to effect improvements in areas where their skills are lacking. In this study, mentoring and observations were deemed to be a primary source of such role models, and it appeared that instructors' belief in their own abilities was enhanced through active reflection on the behaviors of their mentors and colleagues.

Other researchers have stated that mentors have an important role to play as both role models and motivators (Shukri \& Leil, 2017), suggesting that mentored instructors' level of belief in their own ability was more likely to be high when they felt that they had received support from their mentors (Moulding et al., 2014).

Of specific importance to the ELI, a study was undertaken by Asif and Khojah (2020) to explore how female EFL instructors perceived their mentoring program and how it influenced their teaching practice. The outcomes revealed that the participants were generally positive about their participation in the program, demonstrating that introducing such a mentoring program can be highly beneficial to mentees, mentors, and the institution as a whole.

Another point raised by the instructors in relation to their efficacy belief can be traced to their experiences of classroom observation and the feedback received. The participants' responses revealed a degree of inconsistency in how the teachers viewed observations and the impact this had on their self-efficacy. It seemed that the instructor's personal evaluation of the success of a lesson did not hold the most significance; rather, the observer's evaluation appeared more significant.

Shukri (2014) reported a comparable finding in the context of ELI. While the majority of the participants agreed that observations played an essential role in enhancing teaching practices, they believed that there was room for improvement in ensuring that observations were fair and honest. They highlighted that it was imperative for observers to maintain a high standard of ethics, understanding, and patience. In addition, the observers pointed out that they should focus on providing positive and constructive feedback as opposed to focusing on the errors made during the lesson. Some scholars have highlighted that, a positive approach is more likely to empower instructors to engage in a process of reflection, through which they can spot their educational needs and strive to improve their practice (O’Leary, 2014; Wragg, 2002).

\section{Conclusion}

The aim of this study was to understand female EFL instructors' perceptions of the effect of professional development training on their self-efficacy. The study found that the instructors had positive perceptions of the professional development they received at the ELI in terms of enhancing their efficacy beliefs. However, despite 
the majority of the interviewees stating that the professional development activities did have an overall positive outcome, some participants reported a conflicting view of classroom observation as a tool for professional development. Although some saw classroom observation as boosting their sense of self-efficacy, others perceived it as engendering efficacy doubt due to the feedback they received.

According to Bandura (1986), "What people think, believe and feel affects how they behave. The natural and extrinsic effects of their actions, in turn, partly determine their thought patterns and affective reactions" (p. 25). From this perspective, and considering the significance of instructors' beliefs in their educational skills, stakeholders should consider initiating quality professional development training activities based on an analysis of teachers' needs, with the specific aim of increasing instructors' practical and content knowledge. This would further enhance instructors' efficacy beliefs, enabling them to create successful instructional and learning experiences.

\section{References}

AlMutlaq, A., Dimitriadi, Y., \& McCrindle, R. (2017). Factors Affecting Academics' Involvement in TEL Continuing Professional Development (CPD). Journal of Education and Practice, 8(10), 142-149.

Aminudin, N. A. (2012). Teachers' perceptions of the impact of professional development on teaching practice: The case of one primary school.

Ashcraft, M. H., \& Moore, A. M. (2009). Mathematics anxiety and the affective drop in performance. Journal of Psychoeducational assessment, 27(3), 197-205. https://doi.org/10.1177/0734282908330580

Avalos, B. (2011). Teacher professional development in teaching and teacher education over ten years. Teaching and Teacher Education, 27(1), 10-20. https://doi.org/10.1016/j.tate.2010.08.007

Bandura, A. (1977). Self-efficacy: toward a unifying theory of behavioral change. Psychological review, 84(2), 191. https://doi.org/10.1037/0033-295x.84.2.191

Bandura, A. (1986). The explanatory and predictive scope of self-efficacy theory. Journal of social and clinical psychology, 4(3), 359-373. https://doi.org/10.1521/jscp.1986.4.3.359

Bandura, A. (1993). Perceived self-efficacy in cognitive development and functioning. Educational psychologist, 28(2), 117-148. https://doi.org/10.1207/s15326985ep2802_3

Bandura, A. (1997). Self-efficacy: Toward a unifying theory of behavioral change (1977). Psychological Review, 84. Bandura, A, 104-118. https://doi.org/10.1037/0033-295x.84.2.191

Blömeke, S., Olsen, R. V., \& Suhl, U. (2016). Relation of student achievement to the quality of their teachers and instructional quality. Teacher quality, instructional quality and student outcomes, 21-50. https://doi.org/10.1007/978-3-319-41252-8_2

Buczynski, S., \& Hansen, C. B. (2010). Impact of professional development on teacher practice: Uncovering connections. Teaching and Teacher Education, 26(3), 599-607. https://doi.org/10.1016/j.tate.2009.09.006

Bulgren, J. A., Deshler, D. D., Schumaker, J. B., \& Lenz, B. K. (2000). The use and effectiveness of analogical instruction in diverse secondary content classrooms. Journal of Educational Psychology, 92(3), 426. https://doi.org/10.1037/0022-0663.92.3.426

Chetty, R., Friedman, J. N., \& Rockoff, J. E. (2013). Measuring the impacts of teachers II: Teacher value-added and student outcomes in adulthood. American economic review, 104(9), 2633-2679. https://doi.org/10.3386/w19424

Chingos, M. M., \& Peterson, P. E. (2011). It's easier to pick a good teacher than to train one: Familiar and new results on the correlates of teacher effectiveness. Economics of Education Review, 30(3), 449-465. https://doi.org/10.1016/j.econedurev.2010.12.010

Coldwell, M. (2017). Exploring the influence of professional development on teacher careers: A path model approach. Teaching and Teacher Education, 61, 189-198. https://doi.org/10.1016/j.tate.2016.10.015

Darling-Hammond, L., \& McLaughlin, M. W. (2011). Policies that support professional development in an era of reform. Phi delta kappan, 92(6), 81-92. https://doi.org/10.1177/003172171109200622

Fives, H., \& Buehl, M. M. (2012). Spring cleaning for the "messy" construct of teachers' beliefs: What are they? Which have been examined? What can they tell us? In K. R. Harris, S. Graham, \& T. Urdan (Eds.), APA educational psychology handbook (pp.471-499). Washington, DC: APA. https://doi.org/10.1037/13274-019

Garet, M. S., Porter, A. C., Desimone, L., Birman, B. F., \& Yoon, K. S. (2001). What makes professional 
development effective? Results from a national sample of teachers. American educational research journal, 38(4), 915-945. https://doi.org/10.3102/00028312038004915

Girvan, C., Conneely, C., \& Tangney, B. (2016). Extending experiential learning in teacher professional development. Teaching and Teacher Education, 58, 129-139. https://doi.org/10.1016/j.tate.2016.04.009

Goe, L. (2007). The link between teacher quality and student outcomes: A research synthesis. National comprehensive center for teacher quality.

Harris, J., Cale, L., \& Musson, H. (2011). The effects of a professional development programme on primary school teachers' perceptions of physical education. Professional Development in Education, 37(2), 291-305. https://doi.org/10.1080/19415257.2010.531973

Hoy, A. W., Davis, H., \& Pape, S. J. (2006). Teacher knowledge and beliefs. In P. A. Alexander, \& P. H. Winne (Eds.), Handbook of educational psychology (2nd Edition, pp. 715-737). Mahwah, NJ: Lawrence Erlbaum. https://doi.org/10.4324/9780203874790.ch31

Justice, L. M., Mashburn, A. J., Hamre, B. K., \& Pianta, R. C. (2008). Quality of language and literacy instruction in preschool classrooms serving at-risk pupils. Early childhood research quarterly, 23(1), 51-68. https://doi.org/10.1016/j.ecresq.2007.09.004

Karimi, M. N. (2011). The effects of professional development initiatives on EFL teachers' degree of self efficacy. Australian Journal of Teacher Education, 36(6), 4. https://doi.org/10.14221/ajte.2011v36n6.6

Khojah, A., \& Asif, F. (2020). Mentoring Matters in Workplace: The Impact of Formal Mentoring Program on EFL Instructors' Performance at ELI, King Abdulaziz University, Saudi Arabia. English Language Teaching, 13(4), 140-161. https://doi.org/10.5539/elt.v13n4p140

Khojah, A., \& Shousha, A. (2020). Academic Accreditation Process of English Language Institute: Challenges and Rewards. Higher Education Studies, 10(2), 176-188. https://doi.org/10.5539/hes.v10n2p176

Klassen, R. M., \& Chiu, M. M. (2010). Effects on teachers' self-efficacy and job satisfaction: Teacher gender, years of experience, and job stress. Journal of Educational Psychology, 102(3), 741. https://doi.org/10.1037/a0019237

Klassen, R. M., \& Tze, V. M. (2014). Teachers' self-efficacy, personality, and teaching effectiveness: A meta-analysis. Educational Research Review, 12, 59-76. https://doi.org/10.1016/j.edurev.2014.06.001

Kurt, H., Güngör, F., \& Ekici, G. (2014). The relationship among teacher efficacy, efficacy regarding teaching, and responsibility for student achievement. Procedia-Social and Behavioral Sciences, 116(21), 802-807. https://doi.org/10.1016/j.sbspro.2014.01.301

Mizell, H. (2010). Why Professional Development Matters. Learning Forward.

Moulding, L. R., Stewart, P. W., \& Dunmeyer, M. L. (2014). Pre-service teachers' sense of efficacy: Relationship to academic ability, student teaching placement characteristics, and mentor support. Teaching and Teacher Education, 41, 60-66. https://doi.org/10.1016/j.tate.2014.03.007

O'Leary, M. (2014). Classroom observation: A guide to the effective observation of teaching and learning: Routledge. https://doi.org/10.4324/9780203119730

Pajares, F. (2003). Self-efficacy beliefs, motivation, and achievement in writing: A review of the literature. Reading \& Writing Quarterly, 19(2), 139-158. https://doi.org/10.1080/10573560308222

Pajares, M. F. (1992). Teachers' beliefs and educational research: Cleaning up a messy construct. Review of educational research, 62(3), 307-332. https://doi.org/10.3102/00346543062003307

Palardy, G. J., \& Rumberger, R. W. (2008). Teacher effectiveness in first grade: The importance of background qualifications, attitudes, and instructional practices for student learning. Educational Evaluation and Policy Analysis, 30(2), 111-140. https://doi.org/10.3102/0162373708317680

Rice, J. K. (2003). Teacher quality: Understanding the effectiveness of teacher attributes. Washington, DC: Economic Policy Institute.

Ross, J., \& Bruce, C. (2007). Teacher self-assessment: A mechanism for facilitating professional growth. Teaching and Teacher Education, 23(2), 146-159. https://doi.org/10.1016/j.tate.2006.04.035

Roy, C. K., Rahim, S., \& Khojah, A. Y. (2018). Perceptions of EFL Teachers at King Abdulaziz University Regarding the Effectiveness of Cambridge University Press's Train the Trainer Course. Arab World English Journal, 9(2), 92-107. https://doi.org/10.24093/awej/vol9no2.6 
Schunk, D. H. (1991). Self-efficacy and academic motivation. Educational psychologist, 26(3-4), 207-231. https://doi.org/10.1080/00461520.1991.9653133

Shidler, L. (2009). The impact of time spent coaching for teacher efficacy on student achievement. Early Childhood Education Journal, 36(5), 453-460. https://doi.org/10.1007/s10643-008-0298-4

Shousha, A. I. (2015). Peer observation of teaching and professional development: Teachers' perspectives at the English language institute, King Abdulaziz University. Arab World English Journal (AWEJ), 6(2), 131-143. https://doi.org/10.2139/ssrn.2834383

Shukri, N. (2014). Exploring Female Teachers' Perceptions towards Teacher Observation: Issues and Challenges in the Arab Context. Arab World English Journal, 5(2).

Shukri, N., \& Leil, A. A. (2017). Female Mentees' Perspectives of a Mentoring program in the Saudi context. The International Journal of Social Sciences and Humanities Invention, 4, 3888-3899. https://doi.org/10.18535/ijsshi/v4i9.01

Tantawy, N. (2020). Investigating Teachers' Perceptions of the Influence of Professional Development on Teachers' Performance and Career Progression. Arab World English Journal (AWEJ), Volume, 11. https://doi.org/10.31235/osf.io/aw48q

Wheatley, K. F. (2005). The case for reconceptualizing teacher efficacy research. Teaching and Teacher Education, 21(7), 747-766. https://doi.org/10.1016/j.tate.2005.05.009

Wragg, E. (2002). An introduction to classroom observation. London \& New York: Routledge. https://doi.org/10.4324/9780203018958

Zambo, R., \& Zambo, D. (2008). The impact of professional development in mathematics on teachers' individual and collective efficacy: The stigma of underperforming. Teacher Education Quarterly, 35(1), 159-168. 


\section{Appendix 1: Interview Protocol}

\section{A- Professional development:}

1. How many years of teaching experience have you had at the ELI?

2. What types of professional development training have you previously participated in? (e.g. Workshops, Trainer Certificate, mentoring program, attending conferences, reading articles or books, joining a discussion group, classroom observations, peer observations, Cambridge University Press's train the trainer course, etc.).

3. How would you describe your experience of professional development training at the ELI?

4. Please can you describe a particularly successful professional development training you participated in at the ELI?

5. Why did you feel that was a successful one?

6. Please can you describe a professional development training you participated in at the ELI that you feel was particularly unsuccessful?

7. Why did you feel that was an unsuccessful one?

\section{B- Self-efficacy}

1. How confident do you feel as an English instructor?

2. How do you think your teaching has an impact on the students' you teach?

3. What do you think are the factors/people that have most affected your confidence as an English instructor?

4. Have you ever doubted your abilities as an English instructor? Why? How did you deal with this?

5. For those that have been mentored - How has your mentor impacted on your confidence as an instructor? How did mentoring affect your teaching practice?

6. Can you describe an experience that has really motivated you as an English instructor to improve your practice?

7. Can you describe how your perceptions of your teaching skills has changed over the last two years? What events/experiences have impacted upon these perceptions

\section{Copyrights}

Copyright for this article is retained by the author(s), with first publication rights granted to the journal.

This is an open-access article distributed under the terms and conditions of the Creative Commons Attribution license (http://creativecommons.org/licenses/by/4.0/). 